\title{
Adaptation of Turkish Loanwords Originating from Arabic
}

\author{
Wafi Fhaid Alshammari ${ }^{1} \&$ Ahmad Radi Alshammari ${ }^{1}$ \\ ${ }^{1}$ Department of English Language, College of Arts, University of Ha'il, Ha'il, Saudi Arabia \\ Correspondence: Wafi Fhaid Alshammari, Assistant Professor of Linguistics, Department of English, College of \\ Arts, University of Ha'il, Hail, Saudi Arabia. E-mail: wf.alshammari@uoh.edu.sa
}

Received: July 26, 2020

Accepted: September 12, 2020

Online Published: September 23, 2020

doi:10.5539/ijel.v10n5p388

URL: https://doi.org/10.5539/ijel.v10n5p388

\begin{abstract}
This study investigates the phonological and morphological adaptation of Turkish loanwords of Arabic origin to reveal aspects of native speakers' knowledge that are not necessarily obvious. It accounts for numerous modification processes that these loanwords undergo when borrowed into Turkish. To achieve this, a corpus of 250 Turkish loanwords was collected and analyzed whereby these loanwords were compared to their Arabic counterparts to reveal phonological processes that Turkish followed to adapt them. Also, it tackles the treatment of morphological markings and compound forms in Turkish loanwords. The results show that adaptation processes are mostly phonological, albeit informed by phonetics and other linguistic factors. It is shown that the adaptation processes are geared towards unmarkedness in that faithfulness to the source input-Arabic - is violated, taking the burden to satisfy Turkish phonological constraints. Turkish loanwords of Arabic origin undergo a number of phonological processes, e.g., substitution, deletion, degemination, vowel harmony, and epenthesis for the purpose of repairing the ill-formedness. The Arabic feminine singular and plural morphemes are treated as part of the root, with fossilized functions of such markers. Also, compound forms are fused and word class is changed to fit the syntactic structure of Turkish. Such loanwords help pave the way to invoke latent native Turkish linguistic constraints.
\end{abstract}

Keywords: phonology, phonological adaptation, loanwords, Arabic, Turkish

\section{Introduction}

Narrowing borrowing down to the lexical level, one can speak of a loanword when it has been transferred into a language (Wohlgemuth, 2009, p. 55). Loanword phonology incorporates a dynamic interaction between the donor and the recipient languages' inventories and structures as well as universal phonological patterns. Loanwords usually undergo adaptation or nativization processes to conform to the linguistic constraints of the native language. Modifications of the phonetic shape applied to loanwords in order to meet the phonological structure of the recipient language are, of course, also instantiations of adaptation. The patterns that emerge in loanword adaptation often reveal aspects of native speakers' knowledge that are not necessarily obvious in data of the native language and, as a result, loanword data enables us to unveil the native phonology (Holden, 1976; Ahn \& Iverson, 2004; Kawahara, 2008; and others). The loss of consonant clusters, for example, should not be a surprise, if the recipient language does not allow complex clusters (Maddieson, 2005, p. 86). The English word fry, for instance, is borrowed as palai in Hawaiian whereby fry has been adjusted to suit Hawaiian phonology by substituting the consonants /f/ and /r/ which are not part of the Hawaiian phoneme inventory and by inserting a vowel to break up the consonant cluster which is not allowed by Hawaiian phonotactics (Wohlgemuth, 2009, p. 74). Thus, the strategies of loanword adaptation through contact situation, such as the one between Turkish and Standard Arabic in the past centuries, may readily be explained by features of the recipient language. Lexical input forms with their own morphological marking integrated in the recipient language are also eligible for being models of loanword. Such forms taken with different amounts of donor language morphology attached to them are not regarded as such by the speakers of the recipient languages, but treated as undetectable forms in the recipient language, just like the bare stems.

Turkish exerted a considerable amount of integration of loanwords from various languages; Arabic and Persian still remain an essential part of Turkish (García et al., 2014; Versteegh, 2011). This study examines one of the emblems of language contact and linguistic interference, namely the use of loanwords. It deals with some of the phonological processes that are applied to Turkish loanwords of Arabic origin in order not to violate the structural constraints of Turkish. More specifically, it tackles substitution, deletion, degemination, vowel 
harmony, and epenthesis, the treatment of the feminine singular and plural markers, which contain lexemes together with their grammatical morphemes, resulting in lexical items with fossilized functions of their grammatical morphemes, i.e., fossilized morphology, i.e., loanwords integrated need not always be uninflected as they are taken as unanalyzable chunks. Furthermore, it investigates compound forms fused with word-class change to fit the syntactic structure of Turkish.

There appears to be some certain amount of replicated wholesale of frozen morphology, materials which are in the Arabic source morphemic, but simply part of a complete lexeme in Turkish. Also, it tackles fusion of compounds and change of word class in order to fit the syntactic structure of Turkish.

This paper proceeds as follows: Section 2 draws a brief linguistic and historical overview on Turkish, loanword phonology and morphology, and Turkish loanwords. Section 3 discusses the data for the current study. Section 4 presents an analysis and discussion. Section 5 concludes this paper with a recommendation for future research.

\section{Literature Review}

\subsection{Linguistic and Historical Overview}

Turkish is the official language of Turkey and one of two official languages of Cyprus, spoken natively by around seventy million native speakers. It consists of three major dialects: Rumelian, Anatolian and Crimean. Today's Standard Turkish, spoken in Istanbul, descends from Anatolian dialect. Turkish is an agglutinative language that descends from Ottoman language, which is a branch of southwestern Turkic languages. Although there is an ongoing debate on the relationship of Turkish to other genetically similar languages, some scholars classify Turkish in the Altaic group, along with Mongol, Tunguz, and possibly Korean, whereas others classify it in the Ural-Altaic group, including Altaic languages, Finish, and Hungarian (McCarthy, 1970, p. 2). The first Turkic empire in Anatolia was established by Seljuqs in the 10th century who adopted Islam. Since Islam was correlated with Arabic, a large amount of loanwords from Arabic had entered to Turkish (Dorleijn, 2006, p. 82; Özçelik, 2014, p. 1198). Many Turks learned Arabic and Persian in the 11th and 12th centuries because the written texts in Turkish were not satisfactory. The context for most of the loanwords taken from Arabic is certain: they are nearly all words connected with the religion, science, and law. Before the 19th century, the language of scholarship and of Islamic law, and the medium of instruction in schools available to the Muslim population was Arabic. In literature, on the other hand, Persian was dominantly influencing the Ottoman literary people (Göksel \& Kerslake, 2005, p. 9). Almost all of the Arabic loanwords were taken from Standard Arabic and not from modern dialects. This resulted in assimilating a huge amount of loanwords into Turkish phonologically and morphologically.

The Turkish language reform in the mid-19th century was initiated by individuals, groups, and the government-inspired campaign to eliminate the Arabic and Persian grammatical features and the many thousands of Arabic and Persian borrowings that had long been part of the language. In 1923, a writer called Tunali Hilmi proposed creating a new law for the Grand National Assembly to build a Commission in the Ministry of Education for the Turkish Language whereby technical terms, school books, official documents, newspapers, and new laws would be Turkicized, however, this proposal did not meet acceptance. Perhaps, the earliest official attempt at simplifying the language was told by H. E. Erkilet, who was appointed to head the Army's Directorate in 1924 (Lewis, 1999, p. 41). Turkish underwent radical changes as part of the revolutionary reform program launched by Mustafa Kemal Atatürk where a comprehensive change in the medium in which Turkish was written, by means of introducing the Latin alphabet in 1928. Also, the official Turkish Language Foundation in 1932 launched a campaign to eliminate Arabic and Persian from the Turkish lexicon (Göksel \& Kerslake, 2005). The major task in reforming processes of Turkish and making it as pure a Turkish as possible was to eliminate the many loanwords, especially those from Arabic and Persian (Lewis, 1999, p. 41; McCarthy, 1970, p. 17). Such prescriptive processes of language planning were implemented through introducing old Turkish words from texts and manuscripts; new meanings were given to existing modern Turkish words, and basing new neologisms to Turkish (McCarthy, 1970).

\subsection{Loanword Phonology and Morphology}

Loanword phonology is a recent field of research that has been developed over the last decades. It is an important and interesting field as it demonstrates the conflicts occurring between structural systems of languages. The term borrowing describes a process when one language adds a word or morpheme from another language to its own lexicon (Fromkin et al., 2007, p. 474). There is no assumption that the 'borrowing' or 'loan' will ever be returned, but these have been firmly entrenched terms in the field. Most loanwords are perceived differently by native speakers of the recipient language. Haugen $(1969$, p. 3) proposes that the phonological adaptation of loanwords is a several-step process. First, a bilingual introduces a new word which closely resembles the native 
form by means of code-switching. Second, with no access to the vocabulary of the donor language, monolinguals rely heavily on forms produced by bilinguals. Therefore, there appear to be some degrees of variation whereby monolinguals attempt to approximate the non-native sound patterns to their native sounds. Third, when the word gets popularized and spread throughout the speech community, it becomes a part of the lexicon of the recipient language. The pronunciation of the borrowed item is often altered to fit the phonological rules of the recipient language. Languages implement various methods in order to incorporate foreign words into their linguistic system. French words containing nasalized vowels, for instance, are integrated through a vowel-nasal sequence. Stachowski (2012, p. 375) provides an interesting example of a Turkish loanword from Arabic origin where it changes slightly to conform to the Turkish phonotactics; the word bember 'pulpit (in the mosque)' (Ar. > minbar > mimbar) applies both assimilation and dissimilation where the $m-m b$ sequence was replaced with $b-m b$ since Turkish disfavors word-initial sonorants. French verbs were adapted to Turkish by means of nominalizing them through the do-construction 'etmek', before the loanwords enter into the native language (Lewis, 1967, p. 156).

Grammatical morphemes of the donor language often survive, but their functions are disregarded and the word is taken as a wholesale lexical chunk wherein the morphology of the recipient language applied. One as such is verbal loanwords from Georgian to Mingrelian where the Georgian thematic vowel [a-] is retained as a fossilized form (Wohlgemuth, 2009, p. 121). However, the morphology that got borrowed along with the loanword may become productive in the recipient language (paradigm insertion), e.g., Ajia Varvara Romani acquired a new inflectional class from Turkish loan verbs for present and past tenses, except for the 1st person plural past tense (Wohlgemuth, 2009, p. 119). The recipient language obligatorily marks these conjugated loanwords in order to fit its syntactic structure (Wohlgemuth, 2009, p. 281).

\subsection{Turkish Loanwords}

Turkish lexicon constitutes a large amount of loanwords coming from different languages. Loanwords from Arabic make up a huge proportion of the vocabulary in Turkish. They also figure largely in the language of everyday communication and some are found even among the most basic vocabulary. The written genre had more than $70 \%$ of its lexicon from Arabic, Persian, and French (Halman, 2007, p. 78). After the Turkish revolutionary reform, lexicon of Turkish origin reached $80 \%$ and relinquished foreign words (Lewis, 1999, p. 84). Khalilzadeh et al. (2012) report that the 2005 edition of the official dictionary of Turkish, Güncel Türkçe Sözlük "Current Turkish Dictionary", contains $86 \%$ of the words with Turkish origin and only $14 \%$ of the lexical items come from other languages, such as Arabic, Persian, French, English, Italian, and Greek.

Modern Turkish is especially characterized by vowel harmony and suffixation with no change in the base form, e.g., gel 'come', gel-ir 'he comes', and gel-iyor 'he is coming' (McCarthy, 1970). To adapt to the phonological patterns of Turkish, loanwords of Arabic origin undergo some processes of change due to the inherent differences of the phonotactics of the two languages. It enables us to gain some insights into the ways in which Turkish followed to Turkify loanwords, e.g., words contained marked sounds, geminate clusters, coda clusters, and the like, none of which are permitted in Turkish phonological system. Arabic requires consonant initial (Watson, 2002, p. 64); however, some of these words of Arabic loanwords in Turkish are substituted with corresponding vowels, e.g., ?udzrah > üjret 'rent/fee' (McCarthy, 1970, pp. 7, 8). While coda geminate clusters are permitted in final position in Arabic, they are reduced or eliminated in Turkish loanwords, e.g., haq 'justice' (Ar. > ћaqq). Table 1 shows the consonant inventory of Turkish (Yavus et al., 2000, p. 21).

Table 1. Consonant inventory of Turkish

\begin{tabular}{|c|c|c|c|c|c|c|c|}
\hline$\underset{\text { manner }}{\text { place }}$ & Bilabial & Labiodental & Alveolar & Palato-alveolar & Palatal & Velar & Glottal \\
\hline stop & $\begin{array}{ll}\mathrm{p} & \mathrm{b}\end{array}$ & & $\mathrm{t} \quad \mathrm{d}$ & & & $\begin{array}{ll}\mathrm{k} & \mathrm{g}\end{array}$ & \\
\hline nasal & $\mathrm{m}$ & & $\mathrm{n}$ & & & & \\
\hline fricative & & $\mathrm{f}$ & $\mathrm{s} \quad \mathrm{z}$ & $\int 3$ & & & $\mathrm{~h}$ \\
\hline approximate & & $\mathrm{v}$ & & & $\mathrm{j}$ & & \\
\hline lateral & & & 1 & & & & \\
\hline flap/tap & & & $\mathrm{r}$ & & & & \\
\hline affricate & & & & $\mathrm{t} \int \mathrm{d} 3$ & & & \\
\hline
\end{tabular}

Turkish has a perfectly symmetric vowel inventory of eight phonemes: four of them front and four back, as shown in Table 2 below (Tezcür, 2013, p. 1197). 
Table 2. Vowel inventory in Turkish

\begin{tabular}{lllll}
\hline & front & & back & \\
\cline { 2 - 5 } & Unround & Round & Unround & Round \\
\hline High & $\mathrm{i}$ & $\ddot{\mathrm{u}}$ & $\mathrm{I}$ & $\mathrm{u}$ \\
Low & $\mathrm{e}$ & $\ddot{\mathrm{o}}$ & $\mathrm{a}$ & $\mathrm{o}$ \\
\hline
\end{tabular}

Although Turkish did not have feminine gender or dual number (Slobin, 2016, p. 107), Arabic loanwords brought to Turkish had to have feminine and dual markers on nouns and adjectives. This influenced original Turkish words, a pseudo-feminine or dual marker would be added to agree with the noun (McCarthy, 1970, p. 13). A host of Arabic morphemes, such as the definite article, have entered Turkish and became inseparable from nouns they entered with, although we find instances where such morphemes were interpreted as separate morphemes, e.g., ceibir 'algebra' (Ar. > al-jabr) where the definite article [al] is deleted (McCarthy, 1970, p. 113). Also, some Arabic prepositional phrases, completely alien to Turkish syntax, were imported more or less as lexical units (Göksel \& Kerslake, 2005, p. 9). In order to compare the two languages - the donor and recipient language - below is the phonetic inventory of Arabic (Watson, 2002, p. 13).

Table 3. Consonant inventory of Arabic

\begin{tabular}{|c|c|c|c|c|c|c|c|c|c|c|c|c|c|c|c|c|}
\hline place & 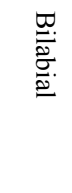 & $\begin{array}{l}5 \\
\tilde{0} \\
\stackrel{0}{0} \\
\stackrel{0}{0}\end{array}$ & 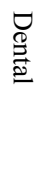 & 然 & $\frac{\frac{E}{9}}{\frac{2}{2}}$ & & 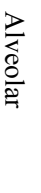 & 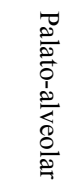 & $\begin{array}{l}\vec{D} \\
\stackrel{\vec{N}}{\vec{N}} \\
\overrightarrow{0}\end{array}$ & 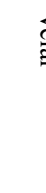 & & & & 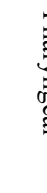 & & 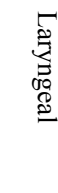 \\
\hline stop & $\mathrm{b}$ & $\mathrm{t} d$ & & & & & & & & $\mathrm{k}$ & $\mathrm{g}$ & $\mathrm{q}$ & & & & $?$ \\
\hline $\begin{array}{l}\text { Emphatic } \\
\text { nasal }\end{array}$ & $\mathrm{m}$ & $\mathrm{t}^{\mathrm{f}}$ & & & & $\mathrm{n}$ & & & & & & & & & & \\
\hline fricative & & $\mathrm{f}$ & & $\theta$ & ð & $\mathrm{s}$ & $\mathrm{z}$ & $\int$ & & & & $\mathrm{x}$ & $\gamma$ & $\hbar$ & $\varsigma$ & $\mathrm{h}$ \\
\hline Emphatic & & & & & $\partial^{\varsigma}$ & & & & & & & & & & & \\
\hline Affricate & & & & & & & & $d_{3}$ & & & & & & & & \\
\hline Trill/tap & & & & & & $\mathrm{r}$ & & & & & & & & & & \\
\hline Lateral & & & & & & 1 & & & & & & & & & & \\
\hline Glide & $\mathrm{w}$ & & & & & & & & $\mathrm{j}$ & & & & & & & \\
\hline
\end{tabular}

Table 4. Vowel inventory of Arabic (Watson, 2002, pp. 21, 22)

\begin{tabular}{lllllll}
\hline & Short & & & Long & & \\
\cline { 2 - 7 } & Front & Central & Back & Front & Central & Back \\
\hline High & i & & u & i: & & u: \\
Mid & & & & & & \\
Low & & a & & & a: & \\
\hline
\end{tabular}

The discussion of the adaptation of Turkish loanwords originating from Arabic will be based on the comparison between Arabic and Turkish. The main targets for the analyses are:

(1) The mapping of non-Turkish Arabic consonants.

(2) The phonological repair strategies that Turkish adapted to overcome undesirable forms in loanwords originating from Arabic, e.g., substitution, deletion, degemination, vowel harmony, and epenthesis.

(3) The treatment of morphological markers (feminine singular and plural markers) and compound forms in Turkish loanwords.

\section{The Data}

The data for this study had been collected from a corpus of previous studies and grammar books of Turkish, such as Turkish: A Comprehensive Grammar and Turkish vocabulary for English speakers-7000 words as well as Turkish/English Dictionaries, such as Turkish Pocket Dictionary, and Langenscheidt's Standard Dictionary. A total number of 250 words were collected and analyzed to discuss the adaptation of Turkish loanwords. A qualitative method was used in analyzing the loanwords collected. The main goal was to compare Turkish 
loanwords with their original Arabic forms. Different kinds of forms emerged through the collection process. To explore the ways in which such loanwords occur, a grounded theory approach was applied (Glaser \& Strauss, 1967) whereby categories of forms emerge during the process of coding, or as Seaman (2008, p. 6) puts it, "[l]et the data speak for themselves". This method helps to detect tendencies of change within the two languages.

Loanwords are grouped according to the similarities of the phonological processes that they follow, i.e., loanwords with substitutions of one sound or more are grouped under the category of substitutions, words with epenthesis are grouped under epenthesis, words with changes in their vowel(s) to conform to Turkish vowel-harmony rules are grouped under vowel harmony, whereas loanwords with Arabic feminine singular and plural forms, and compound forms, but treated as singular form or chunks, are grouped under lexical chunking. After that, each Turkish loanword was compared to its Arabic counterpart and analyzed accordingly. The researcher is a native speaker of Arabic which helps eliciting the Arabic forms of these loanwords easily.

\section{Analysis and Discussion}

In comparing the phonemic mapping between the two languages, most of the consonants that they share-Arabic and Turkish - are mapped faithfully. However, there are various steps for adapting Arabic words to fit within the Turkish phonotactics. Sounds not present in the Turkish phonetic inventory are substituted with native sounds. Another process followed was to simply delete the sound not present; this is especially evident with the pharyngeal fricative [G] and the glottal stop [?]. When deleting a sound, e.g., [Y] or [?], a compensatory lengthening of the preceding vowel is implemented as a repair strategy to overcome this type of deletion. Turkish loanwords with original Arabic CVCC syllable structure with final CC geminate are simplified into CVC by means of deleting one of the geminate members. Vowels harmonize with their preceding vowels in Turkish in terms of backness, roundness and height, or one of these features. Turkish loanwords originating from Arabic apply such a rule mostly where we find modified forms to conform to this rule. Syllable structures not allowed in Turkish are repaired in order to conform to Turkish phonotactics. Turkish do not allow coda cluster, i.e., CVCC; however, it epenthesizes a vowel to break up the cluster, resulting in re-syllabifying the word into CV.CVC. Turkish does not allow the Arabic feminine marker /h/ to surface word finally. Nevertheless, it is substituted with its non-pausal allomorph [at], or its variant(s), e.g., [-et]. Both Arabic feminine singular marker [-at] and feminine plural markers [-a:t] as well as broken plural (i.e., irregular plural forms) in Turkish loanwords are disregarded and taken as inseparable forms. Finally, compound forms (i.e., prepositional phrases) are fused with word-class change to fit Turkish syntactic structure. In order to focus the discussion of how these processes of adaptation happen, a representative data of each category of loanwords is given. It is worth noting that the set we provide is not intended as an exhaustive collection, as we have to exercise a degree of selectivity with regard to forms or usages.

\subsection{Mapping for Non-Turkish Consonants}

\subsubsection{Substitution}

Phonemic mapping between the two languages shows that Arabic phonemes not found in the Turkish phonetic inventory are substituted with a phonetically closest Turkish phoneme. In Table 5, I present Turkish loanwords and their Arabic original forms where marked sounds are substituted with their unmarked corresponding sounds.

Table 5. Substitution of Arabic sounds in Turkish loanwords

\begin{tabular}{|c|c|c|}
\hline Arabic & Turkish & Gloss \\
\hline a. qalam & kalem & Ar. pen/Tur. pencil \\
\hline b. maYðirah & mazeret & excuse \\
\hline c. nika:h & nikah & marriage \\
\hline d. xaja:1 & hajal & imagination \\
\hline e. Pawwal & evvel & before/first \\
\hline f. d`ami:r & zamir & Ar. pronoun/conscience, Tur. pronoun \\
\hline g. Piqtis ${ }^{\varsigma} a: d$ & iktisat & economics \\
\hline h. dzawa:b & cevap & answer \\
\hline
\end{tabular}

In the data in Table 5, the foreign sounds-Arabic - are substituted with the more Turkish-like sounds (Note 1). (5a) shows substitution of the velar stop $k$ for the uvular stop $q$. The dental fricative [ $\delta$ ], in (5b), is substituted with the alveolar fricative [z]. The pharyngeal [ $\mathrm{\hbar}]$ and the velar fricative $[\mathrm{x}]$, in $(5 \mathrm{c}) \&(5 \mathrm{~d})$, respectively, are replaced with the glottal fricative [h]. In (5e), the glottal stop [?] is deleted and the approximant $/ \mathrm{w} /$ is turned into 
a labiodental fricative [v], which is not present in the donor language-Arabic. The emphatic [ $\left.\mathrm{d}^{\mathrm{c}}\right]$ is substituted with the alveolar fricative $[\mathrm{z}]$, in $(5 \mathrm{f})$. The emphatic $\left[\mathrm{s}^{\mathrm{S}}\right]$ in $(5 \mathrm{~g})$ is substituted with the corresponding alveolar fricative [s]. The long vowel in both $(5 \mathrm{~g}) \&(5 \mathrm{~h})$ is shortened. Long vowels occur in words borrowed from Persian and Arabic. They are either originally long vowels or they contained a glottal stop, which is deleted, but together with the preceding vowel composes a long vowel in Turkish (Göksel \& Kerslake, 2005). In (5h), the affricate [d3] resembles the orthographic $c$ (Göksel \& Kerslake, 2005, p. 11), and the voiced bilabial stop [b], similar to the final voiced alveolar [d] in $(1 \mathrm{~g})$, is devoiced/neutralized word finally. More details on final devoicing of Turkish loanwords are shown in Table 6.

Table 6. Final devoicing/neutralization

\begin{tabular}{lll}
\hline Arabic & Turkish & Gloss \\
\hline a. qalb & kalp & heart \\
b. kita:b & kita:p & book \\
c. mufrad & müfret & singular \\
d. muћta:d3 & muhtaç & needy \\
e. maza:d & mezat & auction \\
f. Yajb & ayip & shame \\
g. Yaqrab & akrep & scorpion \\
h. adzda:d & ecdat & ancestors \\
\hline
\end{tabular}

The data in Table 6 show that word-final voiced consonants are devoiced. This is to conform to the Turkish phonotactics where [- continuant] sounds are not allowed to surface. Instead, they turn to their voiceless counterparts. This can be explained in the following rule.

(3) [- continuant $] \rightarrow[$ - voice $] /[]_{\text {word }}$

The equation is different when fricatives come word-finally since they are [+ continuant], as in:

(4) mutadza:wiz $\rightarrow$ mütecaviz 'exceeding'

\subsubsection{Deletion}

Both the glottal stop [?] and the pharyngeal fricative [G] are deleted most of the time. According to (Göksel \& Kerslake, 2005, p. 11), the pharyngeal fricative [G] in Turkish loanwords survives mainly in the speech of some elderly speakers, and is going out of usage. Sometimes, an intervocalic pharyngeal fricative [S] can be compensated with a vowel, resulting in a long vowel. Examples are shown in Table 7.

Table 7. Deletion of sounds not present in Turkish

\begin{tabular}{lll}
\hline Arabic & Turkish & Gloss \\
\hline a. Silm & ilim & science \\
b. ta?li:f & telif & compromise \\
c. ta?di:b & tedip & punishment \\
d. sa:Sah & saat & clock \\
e. tiSda:d & tadat & counting \\
f. fiSl & fi:l & act/verb \\
g. maSlu:m & ma:lu:m & known \\
\hline
\end{tabular}

In the examples in Table 7, the pharyngeal fricative [G] and the glottal stop [?] are deleted (or fused with the preceding vowels). In (7b) ta?li:f $>$ telif where $a \boldsymbol{P}>\boldsymbol{e}$ which represents vowel raising. In (7f), we notice a compensatory lengthening of the preceding vowel; nevertheless, it is not always the case. Similarly, in $(7 \mathrm{~g})$, the pharyngeal fricative $[\mathrm{G}]$ is deleted, but compensated with vowel lengthening in the preceding vowel.

\subsubsection{Geminate Reduction}

While Arabic coda geminates are permitted in final position, they are reduced (i.e., simplified) in Turkish loanwords, e.g., haq 'justice' (Ar. > haqq). Below are some examples. 
Table 8. Geminate reduction in Turkish loanwords

\begin{tabular}{lll}
\hline Arabic & Turkish & Gloss \\
\hline a. ћagg & haq/hak & right/justice \\
b. ðamm & zem & dispraise \\
c. $\varnothing^{\varsigma}$ ann & zan & presumption \\
\hline
\end{tabular}

The CVCC syllable structure of Arabic words in Table 8 contains final geminates. However, these coda geminates have been simplified in Turkish loanwords, which means that Turkish does not like coda geminates. Thus, the repair strategy followed is to reduce the geminate. Also, the example in (8a) shows final devoicing for the final [q] in the Turkish loanword, which is also a characteristic of Turkish (discussed in 4.1.1).

\subsubsection{Vowel Harmony}

Turkish is a prime example of vowel harmony, i.e., long-distance assimilation. It has four back and four front vowels. The latter vowel is known in Turkish to harmonize with the former. Since there are two possible values for [+/- back] and two possible values for [+/- round], the suffix can show four different forms: $/ \mathbf{i} /$ is [- back, -

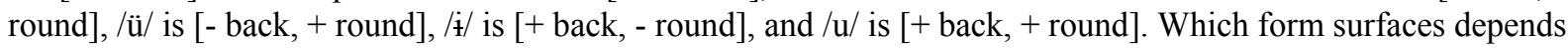
on what values the root has for these features (Nevins, 2010). The same applies to loanwords from Arabic where the latter vowel agrees with the former in backness, roundness, and height, or one of these features, as shown in Table 9.

Table 9. Vowel harmony in Turkish loanwords

\begin{tabular}{lll}
\hline Arabic & Turkish & Gloss \\
\hline a. mudi:r & müdür & manager \\
b. mumkin & mümkün & possible \\
\hline
\end{tabular}

The examples in Table 9 show a process of vowel harmony in Turkish loanwords originating from Arabic. In the Arabic words of $(9 \mathrm{a}) \&(9 \mathrm{~b})$, the first vowel [u] is [+ high, + back, + round], whereas the second [i] is [+high, back, - round]. In Turkish loanwords, the first vowel is [+ high, - back, - round] and the second, unlike its Arabic counterpart, harmonizes to the first in height, backness, and roundness. Thus, we can articulate the following rules in (5) and (6).

(5) Backness harmony $\quad[+$ syllabic $] \rightarrow[+$ back $] /[+$ syllabic,+ back $] \mathrm{C} 1$

(6) Rounding harmony $\quad[+$ syllabic,,+ high $] \rightarrow[+$ round $] /[+$ syllabic,+ round $] \mathrm{C} 1$

It should be noted that it is not always the case that vowel harmonizes in Turkish loanwords, as we find some counter examples in Table 10.

Table 10. No vowel harmony in some Turkish loanwords

\begin{tabular}{lll}
\hline Arabic & Turkish & Gloss \\
\hline a. hisa:b & hesap & Account/bill \\
b. mi $\theta$ a:1 & misal & example \\
\hline
\end{tabular}

Although there is no vowel harmony in the examples above, the examples show vowel reduction. Another note is the substitution of the pharyngeal fricative $[\hbar]$ and the dental fricative $[\theta]$ with $[\mathrm{h}]$ and $[\mathrm{s}]$, respectively.

\subsection{Treatment for Turkish Phonotactics}

\subsubsection{Adaptation of Arabic Coda Cluster (Epenthesis)}

Turkish loanwords with coda cluster are not allowed to surface. Instead, such clusters are repaired through an epenthetic vowel /i/, resulting in re-syllabifying the word to break up the coda cluster. This is shown by the examples in Table 11. 
Table 11. Re-syllabification and epenthesis of Arabic coda cluster

\begin{tabular}{lll}
\hline Arabic & Turkish & Gloss \\
\hline a. Pism & is.im & name \\
b. kibr & ki.bir & arrogance \\
c. Yajb & ay.ip & shame \\
d. Yadl & ad.il & justice/fair \\
e. naqd & na.kit & cash \\
\hline
\end{tabular}

The left column of Table 11 contains Arabic monosyllabic words with CVCC superheavy syllables. Their Turkish loanword counterparts are re-syllabified as CV. CVC with the help of an epenthetic vowel. This indicates that coda clusters are disfavored in Turkish phonological structure.

\subsection{Lexical Chunking}

\subsubsection{Treatment of Arabic Feminine Marker}

Arabic has two allomorphs for the feminine singular marker [-at] and [-ah] where the former occurs in non-pausal and construct state positions and the latter occurs in pausal position (Putten 2017). Turkish adapted the allomorph that occurs in non-pausal and construct state positions, [at] or [-et], since final [h] is disallowed to surface, as shown in Table 12.

Table 12. The feminine marker [-et]

\begin{tabular}{lll}
\hline Arabic & Turkish & Gloss \\
\hline a. maৎðir-ah & mazeret & excuse \\
b. kammijj-ah & kemiyet & quantity \\
c. kafa:l-ah & kefalet & guarantee \\
d. muka:fa?-ah & mükafat & award \\
e. maha:r-ah & maharet & skill \\
f. was ijjj-ah & vasiyet & will/testament \\
\hline
\end{tabular}

The data in Table 12 shows that Turkish had picked up only one environment where the feminine marker [-at] occurs and generalized this to all loanwords ending with the feminine marker [-ah]. It should be noted that this feminine marker is fossilized. The Turkish plural form for vasiyet in (10f), for instance, is vasiyet-lar which is different from its Arabic plural form $>$ was $a: j a$, which indexes that only the singular form was borrowed into Turkish.

\subsubsection{Treatment of Arabic Plural Forms}

Some Arabic words with grammatical markers or compound words are incorporated as chunks (a single word/morpheme) with fossilized morphological marking in Turkish loanwords. For instance, Arabic words with broken plural, i.e., irregular plural forms, are treated as singular forms and the Turkish plural morpheme is added, as shown in Table 13.

Table 13. Arabic plural forms in Turkish loanwords

\begin{tabular}{lllll}
\hline Arabic & Gloss & Turkish & Gloss & Turkish Plural \\
\hline a. amla:k & possessions & emlak & property & emlak-lar \\
b. adabij-a:t & literaries & edebiyat & literature & edebiyat-lar \\
c. a?wwalij-a:t & Priorities/tops & evveliyat & case history/first stag & evveliyat-lar \\
\hline
\end{tabular}

The examples in Table 13 show that Turkish loanwords are treated as lexical chunks with frozen morphological marking or internal structure. In (11a), amlak 'properties' is an irregular plural form, but treated as singular in Turkish whereby the Turkish plural morpheme -lar is added. In (11b) and (11c), the forms are plural in Arabic, as they have the feminine plural suffix [-a:t]. Nevertheless, they are treated as singular forms in Turkish, by adding the plural morpheme -lar. Another issue is the change of word class of the loanword to make it fit within the syntactic structure, as shown in (7). 
(7) Change of word class

\begin{tabular}{|c|c|c|}
\hline a- Arabic form $>\mathrm{maS}$ & $\begin{array}{l}\text { al-Pasaf } \\
\text { with } \\
\text { preposition }\end{array}$ & $\begin{array}{l}\text { 'with regret' } \\
\text { def. regret } \\
\text { noun }\end{array}$ \\
\hline - Turkish loanword > maalesaf & \multicolumn{2}{|c|}{$\begin{array}{l}\text { 'regrettably' } \\
\text { adverb }\end{array}$} \\
\hline b- Arabic form $>$ bina:Pan & $\begin{array}{l}\text { Salaj:h } \\
\text { build-acc } \\
\text { noun }\end{array}$ & $\begin{array}{l}\text { 'according to' } \\
\text { on-obj.pro } \\
\text { preposition-pronoun }\end{array}$ \\
\hline - Turkish loanword $>$ binaenaley & $\begin{array}{l}\text { 'acc } \\
\operatorname{adv}\end{array}$ & ngly/therefore' \\
\hline
\end{tabular}

The Arabic compound form in (7a) consists of the preposition [maS] 'with' and the noun [?asaf] 'regret' which is prefixed with the definite article [al-] to mean 'with regret'. Turkish adapted the compound as one chunk, as an adverb denoting the same meaning. In (7b), the Arabic compound consists of a noun [bina:?] 'construction' with the adverbial marker [-an] to form an adverbial form and the preposition [Cala] 'on' with the object masculine bound pronoun [-i:h], which literally means 'building on that 'masc.'; Turkish composed the two forms as one chunk and treated them as an adverb, carrying the meaning of an idiomatic expression 'accordingly'.

It is interesting to note that although many Arabic lexical items have passed into Turkish as loanwords, some of them have undergone phonological changes. Most loanwords are perceived differently by native speakers of the recipient language. There are various stages in the process of phonological adaptation. Turkish loanwords originating from Arabic witnessed some changes in order to fit the phonotactics of Turkish. One as such is to substitute non-native sounds with their native-sound counterparts or simply delete such non-existing sounds. This is because the phonetic inventory and phonological system of the recipient language do not correspond identically to the ones in the donor language. Therefore, speakers attempt the closest approximation to the model of the donor language, with necessary changes in order to conform to the structural system of their own native language. Of course, variation is evident since there is more than possible phonemic alternation, which I did not tackle as it needs an in-depth sociolinguistic investigation. Arabic emphatics, $\left[\mathrm{s}^{\mathrm{c}}\right],\left[\mathrm{d}^{\mathrm{c}}\right]$, $\left[\mathrm{t}^{\mathrm{q}}\right]$, and $\left[\mathrm{\delta}^{\mathrm{c}}\right]$ do not occur in Turkish loanwords, which is expected since Turkish phonetic inventory does not contain such sounds. Also, the pharyngeal fricative [G] and the glottal stop [?], do not occur in Turkish loanwords most of the time for that they are marked sounds, in addition to being lacked in Turkish phonetic inventory. These sounds are repaired with deletion and compensatory lengthening.

Vowel adaptation is expected to be more complicated and show more asymmetry due to the apparent discrepancy between Arabic and Turkish. Vowel harmony applies to such loanwords to satisfy the phonological constraints of the language. Nonetheless, Turkish loanwords sometimes fail to obey restrictions on vowel harmony. Native speakers can distinguish recently borrowed lexical items from native ones or very old loans purely by means of differences in the phonology. However, loanwords that were adopted many years ago have had more of a chance of being assimilated, especially as Turkish speakers became less aware of the origin. A syllable structure with coda clusters is disfavored in Turkish. Thus, such codas are broken up by an epenthetic vowel, resulting in re-syllabifying the word, e.g., kibr > kibir 'arrogance', or degeminating words with final geminate. As for the treatment of feminine singular and plural markers, only one allomorph [-at, -et] is taken for the feminine singular, with a fossilized function, and incorporating the feminine plural within the lexical item, but also with a fossilized function. In other words, Turkish adapts the whole form, with its morphological marking, but with deactivating the morphological function. Also, the analysis shows a process of word-class change of the loanword so that it fits within the syntactic structure.

\section{Conclusion}

Linguistic analyses through the lens of loanwords provide us with a closer look into the details of the phonotactics of the language and how it favors and disfavors certain linguistic features. The results explicated some phonological processes that Turkish benefit from in order to adapt new words into its linguistic system. Also, it tackled lexical chunking whereby loanwords are taken as wholesale forms with fossilizing their morphological functions and changing word class of compound forms by fusing them into one form.

The more loanwords we analyze, the better the insights we gain. This study would provide better results if we 
incorporated more Turkish loanwords, not only from Arabic origin, but also from other languages. Examining cases of the borrowability of function words and incorporation of grammatical morphemes will provide us with clear-cut insights of language contact and language change, and how new words and forms creep into the language. Finally, this study proves a considerable Arabic contribution to the lexicon of Turkish as it serves as a basis for further research in this field, for it contributes to the previous typological studies on language contact, and loanwords specifically.

\section{References}

Ahn, S.-C., \& Gregory, I. (2004). Dimensions in Korean laryngeal phonology. Journal of East Asian Linguistics, 13, 345-379. https://doi.org/10.1007/s10831-004-4256-x

Dorleijn, M. (2006). Turkish-Kurdish language contact. In B. Hendrik \& J. Lars (Eds.), Turkic languages in contact (pp. 74-94). Wisebaden: Harrassowitz Verlag.

Fromkin, R. R., \& Hyams, N. (2007). An introduction to language. Massachusetts: Thomson Corporation.

García, M., \& Mustafa, Y. (2014). Common vocabulary in Urdu and Turkish language: A case of historical onomasiology. Journal of Pakistan Vision, 15(1), 213-225.

Glaser, B., \& Strauss, A. (1967). The discovery of grounded theory: Strategies for qualitative research. Chicago: Aldine. https://doi.org/10.1097/00006199-196807000-00014

Göksel, A., \& Kerslake, C. (2005). Turkish: A comprehensive grammar. New York: Routledge. https://doi.org/10.4324/9780203340769

Halman, T. (2007). Rapture and revolution: Essays on Turkish literature (J. Warner Ed.). New York: Syracuse University Press.

Haugen, E. (1969). The Norwegian language in America. Bloomington: Indiana University Press.

Holden, K. (1976). Assimilation Rates of Borrowings and Phonological Productivity. Language, 52, 131-147. https://doi.org/10.2307/413213

Kawahara, S. (2008). Phonetic naturalness and unnaturalness in Japanese loanword phonology. Journal of East Asian Linguistics, 17, 317-330. https://doi.org/10.1007/s10831-008-9030-z

Khalilzadeh, A., Ahranjani, A., Poorali, S., Asl, M., \& Akbar, S. (2012). Phonetic, usage and meaning change of Arabic and Farsi loanwords in modern Turkish. International Journal of Academic Research, 4(1), 70-73.

Lewis, G. (1967). Turkish grammar. Oxford: Clarendon Press.

Lewis, G. (1999). The Turkish language reform: A catastrophic success. Oxford: Oxford University Press.

Maddieson, I. (2005). Presence of uncommon consonants. In M. Haspelmath, M. Dryer, D. Gil \& B. Comrie (Eds.), The world Atlas of language structures (pp. 82-85). Oxford: Oxford University Press.

McCarthy, K. (1970). The linguistic adaptation of loanwords in Modern Standard Turkish. PhD Dissertation, University of North Carolina, Chapel Hill.

Nevins, A. (2010). Locality in vowel harmony. Massachusetts: The MIT Press. https://doi.org/10.7551/mitpress/9780262140973.001.0001

Özçelik, Ö. (2014). Turkish Language. In M. Richard (Ed.), Encyclopedia of Islam and the Muslim World (2nd ed., pp. 1197-1199). New York: Macmillan.

Putten, v. M. (2017). The archaic feminine ending - AT in Shammari Arabic. Journal of Semitic Studies, 62(2), 357-369. https://doi.org/10.1093/jss/fgx026

Seaman, J. (2008). Adopting a grounded theory approach to cultural-historical research: Conflicting methodologies or complementary methods? International Journal of Qualitative Methods, 7(1), 1-17. https://doi.org/10.1177/160940690800700101

Slobin, D. (2016). Thinking for speaking and the construction of evidentiality in language contact. In G. Mine, A. Didar, Ö. Balkız \& K. Meltem (Eds.), Exploring the Turkish linguistic landscape: Essays in honor of Eser Erguvanli-Taylan (pp. 105-120). Philadelphia: John Benjamin Publishing Company. https://doi.org/10.1075/slcs.175.07slo

Stachowski, M. (2012). On the consonant adaptation of Arabic (and some Persian) loan-words an Ottoman Turkish dictionary by Arcangelo Carradori (1650). Studia Linguistica Universitatis Iagellonicae Cracoviensis Supplementum, 129. 
Tezcür, G. (2013). Turkish language. In M. Richard (Ed.), Encyclopedia of Islam and the Muslim world (2nd ed., pp. 1197-1199). New York: MacMillan.

Versteegh, K. (2011). Heavy and light borrowing of Arabic verbs. In L. Giuliano \& B. Linda (Eds.), The word in Arabic (pp. 215-228). Leiden: Brill. https://doi.org/10.1163/9789004206427_011

Watson, J. (2002). The phonology and morphology of Arabic. Oxford: Oxford University Press.

Wohlgemuth, J. (2005). A typology of verbal borrowings. Berlin: Mouton de Gruyter.

Yavus, H., Balci, A., \& Ümit, T. (2000). Turkish Phonology, morphology and syntax (Z. Balpinar Ed.). Turkey: Anadulu University.

\section{Notes}

Note 1. Although the Arabic words are written in IPA, their Turkish counterparts are written using the Turkish orthography as it resembles its pronunciation, to a great extent.

\section{Copyrights}

Copyright for this article is retained by the author, with first publication rights granted to the journal.

This is an open-access article distributed under the terms and conditions of the Creative Commons Attribution license (http://creativecommons.org/licenses/by/4.0/). 